\title{
The Role of Principal Leadership in Improving Primary School Teacher Performance in Sanga Desa District Musi Banyuasin Regency
}

\author{
Elis Yuliana ${ }^{1 *}$, Syarwani Ahmad ${ }^{2}$, Syaiful Eddy ${ }^{2}$ \\ ${ }^{1}$ Kindergarten Ngulak, Musi Banyuasin, Indonesia \\ ${ }^{2}$ Universitas PGRI Palembang, Indonesia \\ *Corresponding author.Email: faizahnadira299@gmail.com
}

\begin{abstract}
The problems in this research are: 1) What is the role of the principal's leadership in the elementary school in Sanga Desa District? 2) How is the performance of elementary school teachers in Sanga Desa District? The research subjects in this study are the Principals and Teachers of the Elementary Schools of Sanga Desa District. This research uses a qualitative approach. Data collection techniques used in this study were interviews, observation and documentation. Chronologically, the data steps are: orientation stage, exploration stage, member check stage, triangulation stage, and audit trail stage. The results of this study indicate: 1) The role of the principal's leadership in improving the performance of teachers in SD Negeri in Sanga Desa District is good. Based on the results of the research, it shows that the principal has carried out his duties with full responsibility, by taking a normative approach. 2) The performance of teachers in SD Negeri Sanga Village, Sanga Desa district, has been maximal, seen from the preparation of programs), implementing what has been prepared, and conducting evaluations, and facilitating student talent interest with extracurricular activities.
\end{abstract}

Keywords: Leadership, Teacher Performance, Elementary School

\section{INTRODUCTION}

[1] states that performance as a result of the function of a particular job or activity for a certain period of time or the manifestation of a synergistic combination will be seen from the productivity of a person in carrying out his duties and jobs. According to [2] teacher performance can be interpreted as a teacher's success rate in carrying out educational tasks according to responsibilities based on work standards that have been set to achieve educational goals. Efforts made to achieve good teacher performance require an assessment process. [3] performance appraisal is an activity to assess employee behavior in work both qualitatively and quantitatively.

According to [2] the factors that influence teacher performance also come from outside. Among them is leadership. [4] Leadership is a person's ability to mobilize, influence, work culture, invite, direct, advise, foster, guide, train, instruct, command, prohibit, and even punish with the intention of group members who are part of of the organization willing to work to achieve the goals that have been designed.

In the context of education, according to [5] in the leadership role carried out by the principal, school leadership means influencing all personnel who support the implementation of learning activities in order to achieve educational goals.

[6] educational leadership has two functions, namely: (1) efforts to streamline educational organizations which include a good work ethic, wellmanaged management, seeking educators who have the highest expectations, developing educators as positive role models, provide positive feedback to students, provide good working conditions for educators and business staff, give responsibility to students, and share activities between educators and students; (2) make educational institutions / schools successful which includes the implementation of leadership functions by placing curriculum implementation as the main objective, emphasizing the quality of teaching and learning, have clear goals and high expectations of educators, are able to develop a good organizational 
climate, carry out monitoring and evaluation as part of the organizational work culture, manage staff development, and involve community support in its development. [7] It is of course a problem if the school has not been able to perform a good school management function which will have an impact on the quality of education in the school.

From the data from the results of teacher performance appraisals that have been carried out by assessors at elementary schools in Sanga Desa District, it is known that the average value of teacher competency levels obtained is 46.17. This shows that the teacher's level of competence is sufficient. There are many teachers who do not yet have a good level of competence. This is reinforced by research which shows that autocratic, militaristic, paternalistic, charismatic, and democratic leadership styles have a significant simultaneous influence on teacher performance and the most influential is democratic leadership styles. Furthermore, research conducted by, shows that there is a significant contribution between the supervision of school supervisors on teacher performance.There is a significant contribution of work culture to teacher performance, and there is a significant contribution jointly to the supervision of school supervisors, the leadership style of the principal, and teacher culture on teacher performance. Scientific research written by [8] argues that leadership style affects teacher performance.

Therefore, [3] in order to obtain the quality of education that is in accordance with the goals set, teachers are required to always have high performance. Thus, this teacher performance problem needs serious attention. Starting from the above background, the researchers conducted research on teacher performance in terms of the implementation of the principal's leadership function.

\section{METHODS}

This study uses a qualitative approach to the implementation of the research. What is meant by qualitative research is a research procedure that uses descriptive data in the form of written or spoken words from people and observable behavior [9].

Qualitative descriptive research is research that studies problems in society, as well as the procedures that apply in society and situations, including relationships, activities, attitudes, views, and ongoing processes and the effects of a phenomena in this study, researchers develop concepts and collect facts, but do not test hypotheses. During the research, the researcher is the main instrument. In the data collection effort, five steps will be taken to check and check and analyze the data. Chronologically the steps are: the orientation stage, the exploration stage, the member check stage, the triangulation stage, and the audit trail stage.

\section{RESULTS AND DISCUSSION}

\section{a. The leadership role of the principal of the primary school in Sanga Desa District}

[10] revealed that school principals play an important role in creating teacher work motivation and discipline in educational institutions. Other than that,The principal plays a role as the most important factor in improving the quality of education, the principal is also a manager in addition to teachers. The point is that if to improve the quality of students, good and professional teachers are needed, then to make qualified teachers the principals become educators (educators), managers, administrators, supervisors, leaders, innovators, and motivators.In addition, [11], the back and forth of a school is very dependent on the leadership of the principal even though there are many other factors that determine the progress and decline of a school.

The ownership of the principal in improving the quality of education at SD Negei, Sanga Desa District is inseparable from the existence of supporting and inhibiting factors, and a planned program will not run and succeed optimally if various factors are not available, and supporting factors can come from internal and externally, and in the implementation of improving the quality of schools, broadly and fundamentally what is really needed is support from various parties, this support can be in the form of solidarity, financial support, human resources, and their thoughts, other infrastructure is also an important supporting factor.

\section{b. The performance of primary school teachers in Sanga Desa District}

[4] explain that professional teachers can be seen from the way the teacher behaves, for example teachers are willing to work hard in achieving the school's vision and mission. The same thing was explained by. Teachers who have high enthusiasm are one of the supporting factors in improving quality because teachers have the willingness to work hard by devoting all their abilities, both physically, the material and the totality of themselves which is also seen from the preparation of programs (prota, promes), implementing what has been prepared, and conducting evaluations. , and facilitate students' interest in talents with extracurricular activities.

The results that have been achieved when public elementary school teachers in Sanga Desa subdistrict show an improvement in both completing learning tools according to what they get. From the selfdevelopment program, because teachers follow training, the effect is that teacher administration is more organized. Another achievement was that students were able to compete in the competition arena at the sub- 
district, district and provincial levels. Like mtq champions, table tennis, scouts, Indonesian speeches and many other championships in other competitions, this competency is used to improve student achievement to help students in forming strong mental and knowledge formation. With family communication owned by the principal.

\section{CONCLUSION}

The role of the principal's leadership in improving the performance of teachers in SD Negeri in Sanga Desa District is already good, based on the results of the research, it shows that the principal has carried out his duties with full responsibility, by taking a normative approach, which can persuade or motivate teachers to always work accordingly. with their respective duties, with expertise in the field of study they teach. The procedures and steps taken by the principal in improving the performance of teachers in SD Negeri Sanga Desa Subdistrict are supervising with the approach of deliberation, communication, planning, coordination, evaluation, with this application ultimately all intentions will be realized, to improve teacher performance.

The performance of teachers in SD Negeri Sanga Village, Sanga Desa sub-district has been quite maximal, seen from the preparation of programs (prota, promes), implementing what has been prepared, and conducting evaluations, and facilitating students' talent interests with extracurricular activities in the scouting, PMR, piadato fields. language, Mtq table tennis, and others, and support students in competitions at both the sub-district and district levels. The results achieved show that most graduates can continue to school both public and private, and can compete in the competition arena at both the sub-district and district levels. A comfortable working climate and good communication with stakeholders, teachers are even better in terms of administration such as in learning equipment.

\section{ACKNOWLEDGMENT}

Foremost, I would like to express my sincere gratitude to my advisors Dr. Syarwani Ahmad, M.M and Dr. Syaiful Eddy, M.Si. for the continuous support of master study and research, for their patience, motivation, enthusiasm, and immense knowledge. Their guidance helped me in all the time of research and writing of this thesis. I could not have imagined having a better advisors and mentor for my master study.

My sincere thanks also go to the principals of elementary school in Sanga Desa. Last but not the least, I would like to thank my family: my parents, husband, and children for being beside me throughout my life.

\section{REFERENCES}

[1] Susanto, A. (2013). Theory Learning and Learning at Primary school. Jakarta: Golden Prenada Media Group.

[2] Barnawi., \& Arifin, M. (2014). Professional Teacher Performance. Yogyakarta: Ar-Ruzz Media.

[3] Lian, B., Kristiawan, M. Primasari \& Prasetyo (2020). Teacher's Models in Buliding Students' Character. Journal of Critical Reviews. Vol. 3 (14).

[4] Damayanti, T., Arafat, Y., Eddy, S. (2020). Influence Leadership Head School and Motivation Work To Performance Teacher. Journal of Innovation in Teaching and Instructional Media. Vol 1 (1). 4657.

[5] Arafat, Y. (2017). The Effect of Organizational Culture and Work Performance among the Private Universities' Full Time Faculties in South Sumatra Province. Journal of International Information Institute. 20 (8).

[6] Fitriah, H. (2018). The Influence of Organization Culture and Trust through the Private Teacher Performance in Private Secondary School in Palembang. International Journal of Scientific and Technology. 7 (7).

[7] Marce, S., Ahmad, S., Eddy, S., Principal Management as Administrator in Teacher's Competency Development. Dawuh. Vol 1 (1).

[8] Iskandar, U. (2002). Principal Leadership in Improvement Performance Teacher. Journal of Educational Science Vision. 1 (2), 1018-1028.

[9] Moleong, L. J. (2002). Methodology Qualitative Research. Bandung: teenager Rosdakarya.

[10] Alhusaini, A. Kristiawan, M. Eddy, S. (2020). The Effect of Work Motivation and Work Discipline to Performance Teacher. Journal Education Tambusai. Vol 4 (3). 2166-2172.

[11] Utamy, R. Ahmad, S. Eddy, S. Implementation of Human Resources. Journal of Education Research. 1 (3). 226-236.

[12] Saputra, B. R., Adha, M. A., Ariyanti, N. S., \& Gunawan, I. (2019, December). Tips for Principal in Managing One Roof School (SATAP) in Underdeveloped Area. In the 4th International Conference on Education and Management (COEMA 2019). Atlantis Press.

[13] Hardika, H., Aisyah, E. N., \& Gunawan, I. (2018, October). Facilitative Learning To Improve 
Student Learning Creativity. In 3rd International Conference On Educational Management And Administration (Coema 2018). Atlantis Press.

[14] Agustina, N. E., Sumarsono, R. B., \& Gunawan, I. (2018, September). Implementation Of School And Community Relationship Techniques (A Case Study In SDN Karangbesuki 2 Malang, Indonesia). In 1st International Conference On Early Childhood And Primary Education (ECPE 2018). Atlantis Press.

[15] Bafadal, I., Nurabadi, A., \& Gunawan, I. (2018, December). The Influence Of Instructional
Leadership, Change Leadership, And Spiritual Leadership Applied At Schools To Teachers' Performance Quality. In International Conference On Education And Technology (ICET 2018). Atlantis Press.

[16] Pambudi, B. A., \& Gunawan, I. (2019, December). Instructional Leadership as an Effort to Increase Teacher Professionalism in the Industrial Revolution Era 4.0. In the 4th International Conference on Education and Management (COEMA 2019). Atlantis Press. 